\title{
Challenges and Measures of the Financial Department of Chinese Universities under the New Personal Income Tax Laws
}

\author{
Huan Zhang \\ Financial Department, Jianghan University, Wuhan, Hubei, 430056, China
}

\begin{abstract}
The withholding of personal income tax is an important work of financial department in colleges and universities. The new tax law implemented in 2019 has introduced a series of measures such as special additional deductions, which make the financial department of colleges and universities face new challenges. Starting from the positive and negative effects of the new personal tax law on the macro level, this paper further analyzes the positive and negative effects of the new personal tax law on the financial department of colleges and universities, and puts forward the overall and special measures to deal with the new personal tax law and provide corresponding countermeasures and suggestions for the financial department of colleges and universities.
\end{abstract}

Keywords: New Personal Tax Law, Colleges and universities, Finance department, Challenges, Countermeasures.

\section{Introduction}

The seventh revision of the Personal Income Tax Law in 2018 came into effect on January 1, 2019. Under the new tax law, the threshold of tax payment rose again; the tax calculation and levy mode is changed to "Combination of classification levy tax and comprehensive levy tax"; 6 special additional deductions added and so on. In this context, tax incentives have generally risen, especially for middle and low income group of people. It is making taxes fairer and narrowing the gap between the rich and the poor. For colleges and universities, the amount of financial work of personal income tax has increased. With the higher tax risks, the difficulty of tax planning has also increased, which needs to be paid more attention by the leader of colleges and universities, and deal with it effectively.

\section{The Benefits and Shortcomings Brought by the New Tax Law}

\subsection{The Welfare Brought by the New Personal Income Tax Law}

2.1.1 Fairer Tax burden and more scientific classification of tax items

The reform changed the overall tax levy model into "a combination of classification levy tax and comprehensive levy tax" model. The threshold of tax payment was raised from 3,500 Yuan to 5,000 Yuan, an increase of 42.86 percent, which benefiting more low-income groups. As can be seen from the following Table1, the three lower income brackets of 3 percent, 10 percent and 20 percent have been widened, and the 25 percent income brackets have been stabled correspondingly, while the other three income brackets remain unchanged.

As shown in the Table1, the first four income brackets of tax rates have been further widened, Therefore, it indicating that more middle and low income people have enjoyed the welfare of the tax reform. According to calculation, the average tax rate of the income group those pre-tax income between 2000 Yuan and 38,600 Yuan per month decreased; For income groups with pretax income over 38,600 Yuan per month, their average tax rate will increase. This situation is reflecting the tax principle of ability-to-pay and narrowing the gap between the rich and the poor. The biggest reduction in average tax rates has been for residents whose earning is between 8,000 and 9,000 Yuan a month. For residents whose earning is less than 20,000 Yuan, the tax burden will be reduced to less than 50 percent.

Table1: Annual personal income tax withholding rate table

\begin{tabular}{|c|c|c|c|}
\hline Grades & $\begin{array}{c}\text { Accumulated withholding } \\
\text { and prepayment of taxable } \\
\text { income } \\
\text { (Yuan) }\end{array}$ & $\begin{array}{c}\text { Prepayment } \\
\text { Rate(\%) }\end{array}$ & $\begin{array}{c}\text { Quick } \\
\text { deduction } \\
\text { factor } \\
\text { (Yuan) }\end{array}$ \\
\hline 1 & Below36,000 & 3 & 0 \\
\hline 2 & 36,000 to 144,000 & 10 & 2,520 \\
\hline 3 & 144,000 to 300,000 & 20 & 16,920 \\
\hline 4 & 300,000 to 420,000 & 25 & 31,920 \\
\hline 5 & 420,000 to 660,000 & 30 & 52,920 \\
\hline 6 & 660,000 to 960,000 & 35 & 85,920 \\
\hline 7 & Above 960,000 & 45 & 181,920 \\
\hline
\end{tabular}

According to statistics, after the reform was implemented on a trial basis in 2018, personal income tax was reduced by 31.6 billion Yuan. More than 60 million people who should have to pay taxes will now not have to pay them.14 In the first three quarters of 2019, an additional 442.6 billion Yuan of tax cuts was made in the reform of personal income tax, with a cumulative per capita tax cut of 1,764 Yuan.19 These welfare increases residents' personal disposable income and effectively boosts domestic demand.

Moreover, classification of tax items is more scientific. Take remuneration of labor as an example, the income from remuneration is no longer classified as capital income and is distinguished from interest, dividends and bonus.

In addition, the new tax law adds donation deductions and anti-tax avoidance provisions. 


\subsubsection{Tax efficiency improved}

The mobile application - Personal Income Tax, officially recommended by the State Administration of Taxation, uses contactless online tax filing. Disclaimers use smart phones to file tax returns faster and more actively. Personal residents can choose the two modes between independent declaration by himself or herself and employing units' declaration and withholding. After that year's advance payment, in the next year from March to June when the final settlement of the payment, it is possible to make up the tax or refund, and the refund money can be directly transfer into the personal bank card which is tied to the application before.

2.1.3 Six special additional deductions were added to increase the happiness of taxpayers

The six special additional deductions are: children's education, continuing education, medical treatment for serious diseases, housing loan interest or housing rent, and supporting the elderly. Among them, children's full-time education deduction, according to 1000 Yuan/month/person. The medical deduction for serious illness, even the illness of the family members is also taken into account. The actual personal burden which is more than 15,000 Yuan and within the 80000 Yuan limit will be deducted. The first mortgage can be deducted 1,000 Yuan per month. Monthly deduction of housing rent's amount is based on three kinds of city scale, generated 800, 1,100 and 1,500 Yuan three grades of deduction. Children to support the elderly project, the only child can deduct 2,000 Yuan; Non-only children can share with siblings.

These special additional deductions benefited 44 million taxpayers in 2018, as the State Administration of Taxation leader, Wan Jun(2019a) cited at the 28th National Tax Propaganda Month Theme Forum.

\subsection{The New Personal Income Tax Law Still Exist Inadequacies}

2.2.1 The tax rate remains high, without taking into account regional differences and dynamic adjustment mechanisms

First of all, today, China is still a developing country. In the last century, the top marginal tax rate in developed countries is usually 5-25 percentage points higher than China. However, in recent years, personal income tax rates in developed countries have dropped below 35 percent as a result of a global tax-cutting campaign. But China has not followed this tendency. Therefore, we can see a top tax rate of 45 percent in Table 1.

Secondly, there are no classification of Chinese cities by personal income or Gross Domestic Product to adjust the personal income tax rates of residents in different cities. Residents of big cities such as Beijing, Shanghai, Guangzhou and Shenzhen have far higher incomes than other cities' residents. At the same time, what's more, China has not adjusted the personal income tax rate according to the income level differences of provinces, autonomous region, municipalities directly under the central government, special economic zones and other regions. In fact, the income of provinces and cities in the eastern coastal areas is higher than that of the central and western provinces and cities.

In addition, the tax rate setting does not take into account the inflation rate and other indicators as additional adjustment. The indexed adjustment mechanism is a dynamic adjustment mechanism, we can adjust personal income tax rate according to the inflation rate, growth rate of Gross Domestic Product, growth rate of Consumer price index, and other indicators. Thus, these adjustments will make personal income tax rate more scientific and reasonable, and adjust income distribution more precisely and effectively.

\subsubsection{Tax is not calculated on a household basis}

For example, the special additional deduction items include children's support for the elderly. It is stipulated that those who have more than two children may be designated to one person to enjoy the deduction or may share the deduction equally by each other. However, due to the large income difference between the children of families with many children, some members of this kind of families always struggle for the right to deduct, and produce conflicts. In practice, due to the income inequality between children, some children did not reach the threshold because of low income, the deduction directly designated to high-income children enjoy the tax relief.

In addition, there is a " $4+2+1$ " model of family, that is, one couple takes care of one child, and also take care of four old people. In this model, the special additional deduction for supporting the elderly does not consider the husband's parents-in-law, which is not harmonious enough.

2.2.3 The special additional deduction items are not complete enough and the preferential strength is not strong enough

Take continuing education special additional deduction as an example. In practice, most of time, the taxpayer has to obtain professional skill certificate to get deduction, such as lawyer certificate, certified public accountant certificate and so on. Other completion certificates are difficult to be admitted by the tax bureau. Moreover, the key shortcoming is that the deduction amount is so small, at 400 Yuan a month, that they are negligible compared to the expenses of continuous professional developments of taxpayers. In addition, all kinds of training expenses for personal residents in order to improve their working ability and professional skills are not deducted.

In addition, poor consideration is given to the major difficulties that affect personal income, such as the high cost of chronic diseases, sudden family disasters, car accidents, floods, earthquakes and so on. Moreover, there is also not enough consideration given to the special circumstances of personals, such as widowers, orphans, martyrs and so on. 


\section{The New Personal Income Tax Law Bring Challenges to the Financial Departments of Colleges and Universities}

\subsection{The University Staff Group is Complex, cannot Unify the Work Process of Personal Income Tax}

The personal income difference among the college staffs result from the variance of their positional title and administrative rank. Regardless of external professors and foreign teachers, the highest income group, including school president, their annual income is almost ten times to the lowest income group, such as logistic staff. The high-income group is mainly composed of university leaders, academicians, professors, and scientific research and teaching personnel with equal or higher titles. The reform has little impact on low-income teaching staff, because low-income groups in colleges and universities, their taxable income at least above the threshold. For the income group which has a large monthly income volatility, that is, the annual income is not very high, but some months' taxable income is prominent high. This group need legal tax planning in order to avoid too much tax payment. Those who have lecture fees, review fees and author's remuneration in addition to their salaries are often identified as high-end talents by the school. Because their withholding rate is usually higher than the final settlement of the appropriate tax rate, so usually involved in tax rebates. Therefore, they are the income group, which should be focus on by financial department of colleges for tax planning.

If an external professor with a Chinese nationality, he or she has earned income from at least two sources, so he or she need a separate tax declaration. While, foreign personals, such as foreign teachers and foreign students, whether they need pay personal income tax or not, depends on whether they are regarded as residents. In new personal income tax law, resident is a person who have resided in China for 183 days or more in one year, and he or she is required to pay personal income tax.

Based on the above analysis, due to the large number of college employees, different groups have different tax risks and tax declaration needs.

\subsection{The Income of Faculty and Staff is Diversified, and it is Difficult to Define the Categories of Tax Item}

The salaries of university staff mainly include: basic salary, salary scale, subsidies, performance pay, research performance and annual one-time bonus, etc.

In addition to the normal salary and annual one-time bonus, the faculty and staff still have class pay, invigilation fee, excessive workload class fee, marking fee, graduation thesis guidance fee, accounting and legal consultation fee, design fee, etc. These should be properly distributed among the categories of labor income, royalties advances, author's remuneration and other tax items.
The college students' income includes: work-study income, research grants, scholarships and grand-in-aid. The Chinese names of scholarships and grants are one letter apart, but the difference in nature determines whether they are taxable or not.

\subsection{The Principal-Agent Relationship Between Colleges and its Staffs and Students in Tax Declaration is Not Very Clear}

At present, the new personal income tax law stipulates that college and university employees can declare personal income tax on their own, or they can declare their tax and withheld by their colleges which act as an agent. However, universities do not absolutely have the legal right to check and correct the staffs and students' personal income tax information. On the one hand, if the staffs want the financial department to declare tax for them, the college have to act as an agent to declare, and cannot refuse this application. If the financial department discovered false information in a staff's tax declaration, financial personnel should remind him or her to correct. If the staff refuses to change, they have to report to tax authority. On the other hand, colleges and universities are obligated to withhold and assist tax authorities. Therefore, the financial department of colleges and universities is an applicant when withholding and paying tax, and when verifying the employee's tax data and information, it will become an examiner or an auditor. In addition, colleges and universities also need to engaged in some labor contracts and agreements between itself and their employees. Therefore, financial department must do a good job in contracts and agreements management.

\subsection{The Internal and External Information Systems are not Connected, and the Tax Payment Data and Information Need to be Integrated}

The financial department want to do a good job of agent tax declaration and withholding of personal income tax, they must do a good job of tax information and data collection and review at first. The premise of this work is to build a good tax information platform on campus and connect it with the tax information system of the tax authorities.

From the perspective of the university, the integration of personal income tax information should be dominated by the financial information system of financial department and extended to subordinate units which have tax-related employees, the internal information system must cover students, personnel, wages and salary, academic, and foreign affairs data and information, etc. From the outside perspective, the finance department's external information system must connect to the local tax authority through the tax filing system.

At present, the income source of college staffs is diversified, and the way of settlement is diverse. Cash receipts and payments almost disappear, bank transfers continue to reduce, more on-line payment place is emerging such as WeChat pay and Alipay and other settlements. When the financial 
department of the university declares persona income tax, the employee needs to confirm each income stream one by one. This income settlement trend increases the difficulty to both college financial department and tax authorities in checking the tax data and information.

\subsection{Lack of Tax Evaluation Rules and Mechanism}

The new personal income tax law has no legal constraints and compulsory requirements on the personal income tax assessment. The financial departments of colleges and universities are not obliged to introduce their own tax assessment methods or set up special rules and regulation, so they must not employ Chinese Certified Tax Agents, Chinese Certified Public Accountants or Association of Chartered Certified Accountants and so on to assist in their tax declaration and withholding work.

In the absence of regulation and post, the financial department has to arrange spare full-time or part-time staff to do the heavy workload of tax declaration. Therefore, some tax risks will rise: (1) the revenue missing bookkeeping, (2) income information is not imported into the tax system for deduction, and (3) pre-tax or after-tax amount calculation errors. On the other hand, the personal income tax work process is difficult to standardize, resulting in the inability to timely and effectively meet the needs of different taxpayer groups of colleges and universities.

\subsection{The Space of Tax Planning is Reduced, the Difficulty of I it Is Increased}

Before the introduction of the tax levy model - "a combination of classification levy tax and comprehensive levy tax", the financial departments of colleges and universities usually suggest that employees pay labor income, author's remuneration and royalty advances not more than 800 Yuan evenly in each monthly distribution to avoid tax. At present, after the new levy model mentioned above, taxpayer prepay personal income tax monthly by classification method, next year the comprehensive method generates final payment which leads to payable or refundable amount. Therefore, original tax planning method which mentioned above cannot bring about tax saving effects. So, such simple planning method is completely ineffective.

On the other hand, according to the stipulation of CaiShui [2018] No.164 document 1, if college and university employees get annual one-time bonus and meet the provisions of Guo Shuifa [2005] No.9 document 2, before December 31, 2021 , there is also an option of one-time bonuses not being incorporated into the consolidated income of the year. The formula is as follows:

Annual taxable income $=$ annual income - tax-free income deducting expenses - special deduction - special additional deduction - other deductions - donation.

In this formula, the special deduction contains three kinds of social insurance and housing find; special additional deduction contains six items: children's education, continuing education, medical treatment for serious diseases, housing loan interest or housing rent, and supporting the elderly; other deductions consists of occupational annuity and so on.

Under this policy, tax planning proposal is: the annual taxable income to 36000 Yuan as the critical point. Taxable income which is no more than 36,000 Yuan will be levied on a consolidated basis; while taxable income over 36,000 Yuan will be levied on a separate basis. An example is as follows:

Example 1: Teacher A's monthly salary is 5,000 Yuan, performance salary is 10,000 Yuan, and annual one-time bonus is 35,000 Yuan, a total amount of 5 awards, each one is 7,000 Yuan. Assuming that special additional deduction is not taken into account, special deduction is 1,500 Yuan, and occupational annuity is 400 Yuan.

Here, two schemes of tax planning are given below:

Scheme 1: Combined tax calculation of salary and one-time annual bonus:

Taxable income amount $=$

$[(5,000+10,000+35,000)-1500-400-5,000]=43,100$

the amount 43,100 is applicable to the second level in Table 1

Tax payable $=43,100 \times 10 \%-2,520=1,790$ Yuan

Scheme 2: Salary and one-time annual bonus are taxed separately

Because $43,100<36,000$ according to the principle of tax planning, the one-time bonus should be declared separately.

Taxable income of wages and salaries $=$

$5,000+10,000-1,500-400-5,000=8,100$

$8,100<36,000$ applicable to Level 1 of Table 1 , one-time annual award of $35,000<36,000$ also applies to Level 1 of Table 1.

Tax payable for wages and salaries $=8,100 \times 3 \%-0=243$ Yuan

Tax payable for annual one-off prize $=35,000 \times 3 \%-0=1,050$ Yuan

The total tax in the second plan is $243+1,050=1,293$ Yuan, which is 497 Yuan less than the tax in the Scheme 1.

However, there are also some tax planning trap ranges, that is, due to an increase in taxable income of 1 Yuan leads to tax rate rise and pay more tax, so that the tax planning will be failed. Therefore, the planning space is more and more small. These trap ranges are shown in the Table 2. The financial departments of colleges should avoid these trap ranges when they use tax planning. 
Table 2: "Trap Range" of annual one-time bonus tax preferencies

\begin{tabular}{|c|c|c|c|c|c|c|}
\hline Grades & One-time bonus amount & Tax Rates(\%) & $\begin{array}{l}\text { Quick deduction factor } \\
\text { (Yuan) }\end{array}$ & Tax payment & After tax amount & Overpaid tax amount of extra 1 Yuan \\
\hline 1 & $36,000.00$ & 3 & 0 & $1,080.00$ & $34,920.00$ & \\
\hline \multirow{3}{*}{2} & $36,001.00$ & \multirow{3}{*}{10} & \multirow{3}{*}{210} & $3,390.10$ & $32,610.90$ & $-2,309.10$ \\
\hline & $38,566.67$ & & & $3,646.67$ & $34,920.00$ & \\
\hline & $144,000.00$ & & & $14,190.00$ & $129,810.00$ & \\
\hline \multirow{3}{*}{3} & $144,001.00$ & \multirow{3}{*}{20} & \multirow{3}{*}{1,410} & $27,390.20$ & $116,610.80$ & $-13,199.20$ \\
\hline & $160,500.00$ & & & $30,690.00$ & $129,810.00$ & \\
\hline & $300,000.00$ & & & $58,590.00$ & $241,410.00$ & \\
\hline \multirow{3}{*}{4} & $300,001.00$ & \multirow{3}{*}{25} & \multirow{3}{*}{2,660} & $72,340.25$ & $227,660.75$ & $-13,749.30$ \\
\hline & $318,333.33$ & & & $76,923.33$ & $298,410.70$ & \\
\hline & $420,000.00$ & & & $102,340.00$ & $317,660.00$ & \\
\hline \multirow{3}{*}{5} & $420,001.00$ & \multirow{3}{*}{30} & \multirow{3}{*}{4,410} & $121,590.30$ & $298,410.70$ & $-19,249.30$ \\
\hline & $447,500.00$ & & & $129,840.00$ & $317,660.00$ & \\
\hline & $660,000.00$ & & & $193,590.00$ & $466,410.00$ & \\
\hline \multirow{3}{*}{6} & $660,001.00$ & \multirow{3}{*}{35} & \multirow{3}{*}{7,160} & $223,840.35$ & $436,160.65$ & $-30,249.40$ \\
\hline & $706,538.46$ & & & $240,128.46$ & $466,410.00$ & \\
\hline & $960,000.00$ & & & $328,840.00$ & $621,160.00$ & \\
\hline \multirow{2}{*}{7} & $960,001.00$ & \multirow{2}{*}{45} & \multirow{2}{*}{15,160} & $416,840.45$ & $543,160.55$ & $-87,999.50$ \\
\hline & $1,120,000.00$ & & & $488,840.00$ & $631,160.00$ & \\
\hline
\end{tabular}

The key to tax planning, therefore, is to allocate the absolute amount of salary and one-time bonuses or their respective proportions of the sum. However, due to salaries and bonus in Chinese public colleges and universities are paid according to national and local government standards, the amount or proportion in the sum of the salary and one-time bonus cannot be changed on purpose. The personnel department of public universities decides the payment time point and amount of salary and bonus, so these tax planning method cannot be carried out smoothly. But, this kind of tax plan can be tried in private colleges and universities in China.

\section{Overall Countermeasures and Suggestions for the New Personal Tax Law}

\subsection{Continue to Lower Marginal Tax Rates}

As a developing country, China's marginal tax rate was not as high as that of developed countries for decades, and the level of tax rates followed OECD member countries' average tax rates, so the tax rate was gradually raised. As shown in Table 1 , the maximum tax rate was 45 percent. Now, however, marginal tax rates in the United States and other developed countries have come down sharply after years of tax-cutting campaigns. On the contrary, our country did not catch up with this new trend in time.

Therefore, it is hereby suggested that the 7 grades tax rate in Table 1 can be reduced to 5 grades. For example, (1) 1 percent tax rate is required if the number is less than 20,000 Yuan. (2) from 20,000 to 100,000 Yuan, tax rate is 5 percent; (3) from 100,000 to 250,000 , tax rate is 15 percent; (4) from 250,000 to 1,000,000 Yuan, tax rate is 25 percent; and (5) More than $1,000,000$ Yuan, tax rate is 35 percent. By using this improvement, it not only reflects the ability-to-pay principal of taxation, but also simplifies the measurement and reduces the tax rate.

In addition, China can also learn from Britain to further simplify the classification, which has only three tax rate grades, that is 10 percent, 22 percent, and 40 percent.

\subsection{Take the Family as Unit of Personal Income Tax} Declaration as Soon as Possible

It will be more scientific and reasonable to take the family as unit of personal income tax declaration, and it will also improve the efficiency of tax collection and reflect fairness. At the same time, it can reduce the conflicts between family members in order to compete for the special additional deduction qualification for supporting the elderly item, and promote family and social harmony.

On the specific, China can learn foreign experience, add "family support coefficient" to adjust threshold. Family support coefficient is the ratio that points to the family total population inside certain limits and employment number, it is the statistical index that reflects the family population burden condition that employment population bears directly. It will balance tax burden with the domestic living expenses circumstance of the personal, what considered different family size and people working. This metric embodies humanity. For example, a family has 3 members but only one person has job. Thus, the family support coefficient is 1.5 , which is equal to the total family size divided by the number of people working. If the normal threshold is 5000 Yuan every month, therefore, the adjusted threshold for this employed person is 7500 Yuan every month, which is equal to the normal threshold multiplied by family support coefficient.

\subsection{Special Additional Deduction can also Draw Lessons from Foreign Experience}

First of all, the declaration data and information of special additional deduction should be verified and confirmed by data and information from departments such as education, health, medical security, People's Bank of China - Chinese central bank, financial supervision and so on. This requires the declaration on-line platform of tax authorities to connect with the above state authorities and departments to ensure the authenticity and accuracy of the declaration data and information.

On this basis, draw lessons from foreign experience to 
increase the items of special additional and preferential strength. For example, in view of the high cost of continuing education, and the problem of too little deductions, China can learn from Japan, which deducts the training fee into the scope of deduction, and the deduction proportion is relatively large.

Another example might be United States of America's SAMS, a taxpayer assistance management system, which collects personal data and information, and offers personalized deductions for their real hardship, such as marital status and sudden illness and so on.

\section{Special Measures and Suggestions for Financial Departments of Colleges and Universities to Deal with the New Personal Income Tax Law}

\subsection{Divide the Teaching Staff into Three Income Groups: High, Middle and Low, and Consider the Others Separately}

The financial department can divide the taxable staffs into three categories according to the scope of responsibilities of the employees and the income difference formed by the different titles and positions.

The first category, high-income group: they earn more than 120,000 Yuan or receive income from two sources and have to declare separately. Including: academician; Chinese external professors; scientific researchers with Associate Researcher title or higher title; teaching staffs with Associate Professor title or higher title, university leaders and so on.

The second category, middle-income groups: teaching staffs with Lecturer title and lower title; Auxiliary teaching staffs, such as librarian, experimenters and other series; administrative personnel, such as division leader and lower position and so on.

The third category: low-income groups: retired employees, logistics workers and so on.

In addition to the above, college student groups should be considered separately, but also the foreign teachers and foreign students. These groups' taxable income should be declared separately.

\subsection{To Accurately Classify Income into Corresponding Tax Items to Ensure Correct Tax Calculation and Measurement}

Only by a deep understanding of the scope of taxation and preferential policies can tax items be accurately divided. Here are some examples:

\subsubsection{Wages and salaries}

They are non-independent labor remuneration, which is related to the labor contract and directly related to the job position.

\subsubsection{One-time bonus for the year}

It's essentially part of wages and salary, but the new personal income tax law allows college staffs to claim it separately until Dec. 31, 2021. One-time bonus for public colleges and universities are one-off, but can be divided into five awards, they are: (a) Advanced Unit for Comprehensive Social Governance, (b) Advanced Unit for Party Building, (c) Archives up to Standard (d) Advanced Unit for Civilized Construction, and (e) Award for achieve Government Target and Responsibility.

\subsubsection{Labor services}

This income earned in spare time by providing services, which is independent of one's job. There are some instance, evaluation fee, invigilation fee, consultation fee and so on.

\subsubsection{Remuneration fee}

This income derived from the publication of academic papers or textbooks.

\subsubsection{The income of retired employees}

Retirement salary is used for elderly care. While, income of retired employee is a service income that has nothing to do with elderly care of the employee, therefore, it should pay tax.

\subsubsection{Grants and research grants}

These two are students' income with a certain degree of contingency, which should be subject to taxable income.

\subsubsection{Scholarship}

It is produced according to the students' academic performance evaluation, which is inevitable and need not pay personal income tax.

\subsubsection{Settling-In Allowance for Introducing Talents}

It is different from family resettlement allowance for retirees who relocate to other places. It does not belong to the tax-free category and should pay personal income tax.

\subsection{Improve the Two-Way Tax Declaration and the Tax Collection after Verification by Tax Authorities}

The current pattern of college and universities' personal income tax declaration is "one-way and double". College employees can choose to declare directly on the mobile phone, and use application - "personal income tax", or choose to be withheld and paid by the university, the employer. When the financial department of the university finds that the declaration data and information of the personal employee is wrong, it can request the employee to correct it.

In this mode of personal income tax declaration, the secondary departments of colleges and universities often 
appoint the reimbursement agent to reimburse the department staff for their income such as labor income. If the agent does not submit the attachment for reimbursement of the staff's income to the financial department, or does not import the taxable income information into the "Withholding client of natural person tax management system", it is a new version of the client software, which is provided for calculating tax to avoid tax leakage risk.

On the other hand, employees who get income from many sources keep their income obtained off campus as their own privacy and do not declare it. Therefore, when taxpayer's participation is low, financial personnel in colleges and universities cannot fully grasp the diversified tax-related data and information of employees, which is very easy to lead to tax evasion.

According to Article 18 of Announcement No.60, 2018 of the Chinese State Administration of Taxation, "Taxpayers shall be responsible for the authenticity, accuracy and completeness of the special additional deduction information submitted."3 Therefore, it is necessary to clarify the main responsibility of the personal staff in colleges and universities, advocate paying taxes in good faith, and eradicate personal fluke psychology and false declaration behavior.

Tax authorities can improve the regulation of personal labor income's collection and management, verify the collection of all high-income groups in the first category, and adopt the method of sampling inspection for middle and low income groups to reduce the risk of tax evasion.

In terms of personal income tax declaration mode, China can learn from the experience of the United States of America and OECD member countries, and establish a two-way declaration system between employers - colleges and universities and employees - staffs, and a third-party tip-off system.

\subsection{Break down Internal and External Information Barriers, and Tax Authorities Shall Confirm the Validity of the Declaration Information}

The ultimate purpose of collecting and integrating tax data and information is to prevent tax evasion. On campus, financial departments of colleges and universities should ensure that their accounting system will import personal income and personal identity information into tax declaration and automatic tax calculation system to obtain after-tax amount before issuing reimbursement. At the same time, the financial information system of colleges and universities should at least connect the information systems of other secondary departments, such as students, personnel, scientific research, educational affairs, schools and logistics departments in the university, so that the tax declaration data can be modified synchronously and updated in real time.

From the outside, the financial department of colleges and universities should fill the tax information on-line, and turn to the district tax authority to verify and confirm. However, tax authorities must connect other authorities and department of government, such as education, public health, medical treatment, civil affairs, notarization, Human resources and Social Security, public security, the Central Bank of China, financial supervision and administration departments, so as to verify the authenticity and accuracy of the information declared by colleges and universities through multiple channels.

On the basis of the above, the financial department of colleges and universities can provide employees with the function of declaration and inquiry on the official website of the university, WeChat official account, the website of the financial department and the financial reimbursement platform.

\subsection{Establish a Tax Assessment Mechanism}

It is suggested that financial departments of colleges and universities prepare a unique tax number for each worker and build a tax file at the same time. On this basis, large universities, which has more than 2,000 employees should issue their own Measures for Personal Income Tax Assessment and Withholding and Payment, and set up specialized posts and professional and technical personnel, such as registered tax agents. Specialized personnel will be responsible for the annual declaration, and connecting with the tax management officer of the District Tax Bureau.

Personalized tax assessment can be carried out for employees with different needs to effectively calculate the tax payable. The guess and estimate steps are as follows: (a) obtain the declaration data of last month, get the cumulative withholding rate and the amount of advance payment, (b) forecast the amount of the current period, calculate the new accumulative amount of pre-paid income, check out whether it step up the grade or not, (c) find out the withholding rate, (d) the tax is calculated and converted to the pre-tax amount.

The guess and estimate is very important, because it is the base of tax planning.

\subsection{Change the Direction and Method of Tax Planning and Focus on the Time Value of Money}

The personal income tax planning principle is to enjoy preferential policies while avoiding tax risks. First of all, the financial departments of colleges and universities should introduce the concept of management accounting, which regards the difference between unplanned tax and planned tax as opportunity income. In the mode of "accumulative withholding and prepayment", tax planning on a monthly basis should focus on the gap between withholding tax rate and actually paid tax rate, and at the same time consider the deferred time value of money, which is essentially interest of the tax payment, caused by the settlement at the end of June of the next year. Specifically, other comprehensive income items except salary income are distributed in the month of lower total income or later in time, forming a smoothing effect and delaying the time of reaching higher cumulative withholding 
tax rate. In this way, the absolute amount of tax savings can occur, as shown in the following example:

Example 2: Teacher B has a payment of 5,000 Yuan, and the comprehensive income of that month is 8,000 Yuan, and the comprehensive income of the next month is 5,000 Yuan.

Here are two schemes of tax planning:

Scheme 1: Payment of remuneration in the current month. We can find the tax rate and respondent fast algorithm deduction in Table 3.

Table 3: Monthly Income Tax Rate Table Since October 2018

\begin{tabular}{|c|c|c|c|}
\hline Grades & $\begin{array}{c}\text { Monthly tax included } \\
\text { income(Yuan) }\end{array}$ & Tax Rates(\%) & $\begin{array}{c}\text { Quick } \\
\text { deduction factor } \\
\text { (Yuan) }\end{array}$ \\
\hline 1 & Below 3,000 & 3 & 0 \\
\hline 2 & 3,000 to 12,000 & 10 & 210 \\
\hline 3 & 12,000 to 25,000 & 20 & 1,410 \\
\hline 4 & 25,000 to 35,000 & 25 & 2,660 \\
\hline 5 & 35,000 to 55,000 & 30 & 4,410 \\
\hline 6 & 55,000 to 80,000 & 35 & 7,160 \\
\hline 7 & Above 80,000 & 45 & 15,160 \\
\hline
\end{tabular}

The tax payable $=$

$(8,000+5,000 \times(1-20 \%) \times(1-30 \%)-5,000] \times 10 \%-210=370$ Yuan

Scheme 2: Payment of remuneration next month

The tax payable $=$

$(5,000+5,000 \times(1-20 \%) \times(1-30 \%)-5,000] \times 3 \%-0=84$ Yuan

Obviously, compared with scheme 1, the tax savings of scheme 2 is $370-84=286$ Yuan

Secondly, there are still some tax items that can be subject to other planning techniques. Here are some analysis:

\subsubsection{Labor services, author's remuneration and royalties}

The principle of decentralization shall be adopted, that is, the payment shall be divided into different years, many times and many people; In high salary income months, pay less of these other comprehensive income.

\subsubsection{The invigilator fee}

Directly from the examiner unit to invigilator personal workers, the invigilator income can be included in the taxable income by 80 percent; And through the college, such as education department, transfer the invigilator fee to the workers, this income will be included in the taxable amount by 100 percent.

\subsubsection{Foreign teachers and foreign students}

Tax planning of this income group should focus on the adjustment of their residence time. For example, a foreign teacher from the first year on September 1 to work in one university, in the second year on June 30 to leave the university, so in two tax years, the total residence time are less than 183 days, he or she will not be identified as a resident taxpayer.
5.6.4 More than two sources of income

Most of time, one income of all the sources is salary income. The worker can choose to reduce the total tax amount by signing a labor contract with the issuing company in another place or several other places, rather than a labor contract.

\subsubsection{Transfer of patents and non-patented technologies}

If the high-end talents, which identified by universities because they usually have high-value scientific research achievements. Because they earn too much income from transferring patents and non-patents technologies, they can directly set up small and micro companies and enjoy the preferential tax conditions for small and micro companies in other tax laws.

\section{Conclusion}

This paper summarizes the advantages and disadvantages of the new personal income tax law at first, clarifies that China's new personal tax law is fairer and more effective than the old one, and brings more welfare to the Chinese people. At the same time, there are still several disadvantages such as higher tax rate, less special additional deductions and so on. Then, it deeply analyzes the challenges brought by the new personal income tax law to the financial departments of colleges and universities in China. The main challenges are the complicated classification of the income groups of staffs and the diversified income of them, and the lack of tax evaluation mechanism, which brings difficulties to the withholding and tax planning of the financial departments. At last, the paper puts forward the measures to deal with the challenge from the overall strategy and the strategy specifically aimed at the colleges and universities. It mainly appeals that the financial departments of universities should break down the internal and external information barriers and introduce the concepts of management accounting to do the detailed tax assessment and planning work on the basis of drawing lessons from foreign experience.

\section{References}

[1] Chinese Ministry of Finance and State Administration of Taxation, (2018), "Notice on the Connection of Preferential Policies after the Amendment of the Personal Income Tax Law," CaiShui [2018] No.164, 2018-12-17.

[2] Chinese State Administration of Taxation, (2005), "Notice of the State Administration of Taxation on Adjusting the Method of Calculating and Levying Personal Income Tax on Personal Obtaining Annual One-time Bonus and Other Issues," Guo Shuifa [2015] No.9, 2005-1-21.

[3] Chinese State administration of taxation, (2018), "Procedures for Operation of Special Additional Deduction for Personal Income Tax," Proclamation No.60, 2018-12-21.

[4] Chunyan Pan, (2015), "Perspective of Problems and Countermeasures by the Analysis of the Collection Data on the Personal Income Tax Collection and Administration of High income Groups," Open Journal of Social Sciences, no.3, pp,124-133. 
[5] Delong Zhang, (2017), "Research on Personal Income Tax Affecting Structure of Resident Consumption Expenditure in China," Modern Economy, no.8, pp. 161-171.

[6] Deng Chunyan, (2021), "Thinking on the New Policy of Personal Income Tax,” Taxpaying, no.6, pp. 13-14.

[7] Fan Linjing, Li Yuanbin, and Zhao Chunfeng, (2021), "Research on Personal Income Tax Planning of Universities under the New Tax Law," Money China, no.6, pp. 167-168.

[8] He Huan, (2020), "Discussion on the Reform of the New Personal Income Tax Law," Taxpaying, no.14, pp. 24-26.

[9] Hongmin Zhao, and Xueye Zhang, (2017), “Analysis and Response of Tax Risk Based on the Way of Personal Income Tax," Science Innovation, no.5, pp. 420-423.

[10] Hu nana, (2019). Research on the Collection of Personal Income Tax by Family in China. Master dissertation. Southwest University of Political Science and Law, Chongqing.

[11] Huang Zhen, (2019). Study on the Issues and Countermeasures of Personal Income Tax Collection and Management under the Background. Master dissertation. Zhengzhou University, Zhengzhou, Henan.

[12] Li Haiying, (2020), "Analysis and Discussion on the Change of Financial Function under the Reform of Personal Income Tax,” Taxpaying, no.23, pp. 28-29.

[13] Li Pengxiang, and Chen Yajuan, (2020), "Research and Thinking on the Reform of Personal Income Tax in Our Country," Taxpaying, no.24, pp. 28-29.

[14] Lin Jiangjing, and Hu Chan, (2020), "The Impact of Personal Income Tax Reform on the Tax Burden of Each Income Group," Taxpaying, no.25, pp. 24-25.

[15] Lin Xuejun, (2020), "Discussion on the Reform of Personal Income Tax to Promote Fair Income Distribution," Taxpaying, no.33, pp. 19-20.

[16] Liu Tingting, (2021), "Discussion on Personal Tax Planning after the Reform of Personal Income Tax," Chinese Market, no.5, pp. 152-153.

[17] Liu Yongchun, (2020). Research on China's Personal Income Tax Reform from the Perspective of Tax Burden. Master dissertation. Neimenggu University, Huhehaote, Neimenggu.

[18] Liu Yunhan, (2020), "Research on the Reform of Personal Income Tax in Colleges and Universities," Journal of Educational Institute of Jilin Province, no.12, pp. 161-165.

[19] Song Chunxia, (2020), "On the Reform of Personal Income Tax," Guangxi Quality Supervision Guide, no.9, pp. 230-232.

[20] Sun Yaru, and Xin Weitong, (2020), "Research on the Risk Management of Personal Income Tax in Universities under the New Tax Law," Administrative Assets and Finance, no.15, pp. 52-53.

[21] Wen Yan, (2013), "The Study on the Personal Income Tax of the Policyholder Dividends and Its Impact on Chinese Insurance Industry," iBusiness, no.5, pp. 58-63.

[22] Wu Shuting, (2018), "Tax Planning of College Personal Income Tax Based on the New Tax Law," Taxpaying, no.31, pp. 41-42.

[23] Xie Jianru, and Dong Jian, (2019), “Tax Planning of University Performance Salary under the New Personal
Income Tax Law," Science and Technology \& Innovation, no.22, pp. 125-126

[24] Xie Pingping, (2019). Research on the Reform and Reconstruction of the Personal Income Tax Collection and Management Mechanism under the new Normal Economy, Take Sanming City as an Example. Master dissertation. Fujian Normal University, Fuzhou, Fujian.

[25] Zhang Yanqun, (2020), "Reflections and Suggestions on the Reform of Personal Income Tax in China," Taxpaying, no.20, pp. 11-12.

[26] Zhao Shubo, Wang Xiuzhe, and Wang Jiahe, (2020), "Research on the Reform of Chinese Personal income tax system," Journal of Guangxi University of Finance and Economics, no.5, pp. 38-45.

\section{Author Profile}

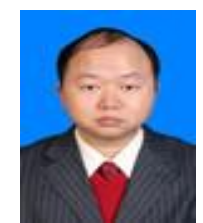

Huan Zhang received the M.S degree of MBA in 2009. He became a non-practicing CICPA in 2017 and the ACCA membership in 2020. $\mathrm{He}$ is now working as a senior accountant in the Finance Department of Jianghan University in Wuhan, Hubei Province, China. 